\title{
CEGAH AMPUTASI DENGAN PENATALAKSANAAN DIABETES MELITUS DI MASA PANDEMI COVID-19
}

\author{
Fitria Alisa1, Vivi Syofia Sapardi², Lola Despitasari ${ }^{3}$, Muhammad Farid ${ }^{4}$, Alex \\ Contesa $^{5}$, Puja Valentino ${ }^{6}$, Cindy Arista ${ }^{7}$, Elvyra Putri, ${ }^{8}$, Tiara Anggraini Herman ${ }^{9}$ \\ 1.3.6.7Prodi S1 Keperawatan / STIKes MERCUBAKTIJAYA Padang \\ 2.8.9Prodi DIII Keperawatan / STIKes MERCUBAKTIJAYA Padang \\ 4.5Klinik MERCUBAKTIJAYA Padang
}

E-mail: vivisyofia1984@gmail.com

\begin{tabular}{l} 
Article History: \\
\hline Received: 31-03-2021 \\
Revised: 05-04-2021 \\
Accepted: 21-04-2021 \\
\\
Kata Kunci : Diabetes \\
Melitus, COVID-19, Latihan \\
Fisik, Kelompok Prolanis DM
\end{tabular}

\begin{abstract}
Abstrak:
Latar Belakang : Diabetes Melitus (DM) merupakan gangguan insufisiensi insulin disebabkan oleh gangguan produk insulin oleh sel beta langerhans atau kurang responsifnya sel tubuh terhadap insulin. Covid-19 menyerang seluruh usia terutama yang mempunyai penyakit kronis (ko-morbid) memiliki risiko terkena lebih sering dengan komplikasi buruk dari penyakit ini. Latihan fisik (senam kaki Diabetik) merupakan salah satu pilar dalam pengelolaan DM berfungsi untuk memperbaiki sensitivitas insulin, dan menjaga kebugaran tubuh di masa Pandemi COVID-19. Tujuan pengabdian masyarakat ini adalah cegah amputasi dengan penatalaksanaan diabetes melitus.
\end{abstract}

Metode : Metode pengabdian masyarakat ini mengacu pada action research dengan pembentukan kelompok prolanis DM di klinik MERCUBAKTIJAYA padang, Sosialisasi dan edukasi terkait penatalaksanaan diabetes melitus, serta Monitoring Evaluasi telah dilaksanakan dan bekerja sama dengan klinik MERCUBAKTIJAYA Padang sebagai tindak lanjut kegiatan ini.

Hasil: Hasil pengabdian di dapatkan $90 \%$ peserta antusias dalam kegiatan dan mampu mempraktekkan kembali materi yang disampaikan.

\begin{tabular}{l}
\hline Abstract: \\
\hline Background : Diabetes mellitus (DM) is an insulin \\
insufficiency disorder caused by disruption of insulin products \\
by Langerhans beta cells or the body's cells are less responsive \\
to insulin. Covid-19 attacks all ages, especially those who have \\
chronic diseases (co-morbid) have a more frequent risk of \\
getting it with bad complications from this disease. Physical \\
exercise (Diabetes leg exercises) is one of the pillars in the \\
management of DM, which functions to improve insulin \\
sensitivity and maintain body fitness during the COVID-19 \\
pandemic. The goal of this community service is to prevent \\
amputation by managing diabetes mellitus.
\end{tabular}


Method : This community service method refers to action research with the formation of a DM prolanis group at the MERCUBAKTIJAYA clinic in Padang, socialization and education related to the management of diabetes mellitus, as well as monitoring and evaluation that have been carried out in collaboration with the MERCUBAKTIJAYA clinic in Padang as a follow-up to this activity.

Result: $90 \%$ of the participants were enthusiastic about the activity and were able to re-practice the material presented.

\section{Pendahuluan}

Pandemi virus korona yang disebabkan oleh SARS-CoV-2 (penyakitnya disebut dengan COVID-19) telah menginfeksi lebih dari 1 juta orang dari berbagai kalangan diseluruh dunia. Data di Indonesia saat ini juga memperlihatkan kecenderungan yang terus meningkat. Penyakit ini relatif baru, memiliki perjalanan penyakit yang cepat dan sangat mudah menular namun sebagian besar sifat-sifatnya masih belum dipahami. Covid-19 ini bisa menyerang hampir seluruh kalangan usia, namun demikian data yang ada saat ini menunjukkan bahwa kelompok usia lanjut dan orang yang mempunyai riwayat penyakit kronis (ko-morbid) memiliki risiko untuk terkena lebih sering dan dengan komplikasi yang lebih buruk dari penyakit ini. Riwayat penyakit kronis yang dimaksud antara lain adalah hipertensi, diabetes melitus, penyakit kardiovaskuler, dan penyakit paru kronis. Khusus untuk mereka dengan diabetes, merupakan komorbiditas kedua tersering ditemukan, sekitar 8\% kasus, setelah hipertensi (Yang et al., 2020) dan dengan angka kematian tiga kali lipat dibandingkan penderita secara umum $(7.3 \%$ berbanding 2.3\%) (Wu \& McGoogan, 2020).

Diabetes Melitus (DM) merupakan salah satu faktor risiko meningkatnya keparahan infeksi COVID-19. Diabetesi yang berusia lebih tua ( $>60$ tahun), kadar gula darah tidak terkontrol, dan adanya komplikasi diabetes dikaitkan dengan prognosis COVID-19 yang buruk. Di China, persentase tingkat kematian diabetes yang terdiagnosa COVID-19 adalah 7.3\%. Di Italia, kematian pada pasien Covid-19 ternyata 36\% berkaitan dengan diabetes (Onder et al., 2020). Laporan dari Philippine - Department of Health (DOH) menunjukkan bahwa diabetes dan hipertensi merupakan komorbid terbanyak pada kematian pasien COVID-19 di Filipina (PERKENI, 2020).

DM merupakan gangguan metabolisme kronis yang ditandai dengan tingginya kadar gula darah sebagai akibat insufisiensi fungsi insulin yang disebabkan oleh gangguan produk insulin oleh sel beta langerhans atau kurang responsifnya sel tubuh terhadap insulin (Masriadi, 2016). DM terdiri dari 3 macam yaitu DM tipe 1, DM tipe 2 dan DM gestasional, dimana diantaranya lebih dari 90\% populasi DM yang dialami oleh masyarakat Indonesia adalah DM tipe 2 sedangkan sisanya 5\%-10 \% adalah DM tipe 1 dan DM gestasional (Tandra 2017).

Berdasarkan International Diabetes Federation (IDF, 2019) jumlah kasus pasien DM di dunia mengalami peningkatan setiap tahunnya. Pada tahun 2011 (366 juta), 2013 (382 juta), 2015 (415 juta), 2017 (425 juta), 2019 (463 juta) dengan tingkat diabetes 
9,0\% pada wanita dan 9,6\% pada pria. Sedangkan diperkirakan tahun 2030 (578 juta), dan 2045 diperkirakan angka kejadian akan terus meningkat menjadi 700 juta jiwa yang akan terdiagnosa DM (Yuen, Saeedi, and Riaz, 2019).

Indonesia menempati peringkat ke -7 terbanyak tahun 2019 untuk penderita DM setelah China, India, USA, Brazir, Mexico yaitu 10,7 juta. Angka kejadian DM diproyeksi dan diperkirakan akan meningkat mencapai 16,6 tahun 2045 (IDF, 2019). Jumlah pasien DM di Indonesia mengalami peningkatan dari 6,9\% tahun 2013 menjadi 8,5\% pada tahun 2018. Sumatera Barat berada diurutan 22 dari 35 provinsi dengan pravelensi pasien DM 1,2\% dan mengalami peningkatan 2,2\% tahun 2018 (Riskesdas, 2018).

Gula darah yang tidak terkontrol merupakan predisposisi diabetis untuk menderita infeksi yang parah. Untuk menghindari hal tersebut, kontrol glikemik yang ketat harus diterapkan setiap saat. Sangat disarankan untuk memiliki alat pemeriksa glukosa darah mandiri sehingga pasien DM dapat melakukan pengecekan glukosa darah dirumah. Individu dengan DM disarankan untuk mengonsumsi asupan diet yang tepat dan latihan fisik di rumah. Hal ini dapat meningkatkan kontrol glikemik dan mengurangi risiko infeksi.

Latihan fisik atau aktifitas fisik merupakan salah satu pilar dalam pengelolaan DM yang berfungsi untuk memperbaiki sensitivitas insulin dan juga untuk menjaga kebugaran tubuh. Latihan fisik bisa membantu memasukan glukosa kedalam sel tanpa membutuhkan insulin, selain itu latihan fisik juga bisa untuk menurunkan berat badan diabetis yang obesitas serta mencegah laju progresivitas gangguan toleransi glukosa menjadi DM. Pada saat tubuh bergerak, akan terjadi peningkatan kebutuhan bahan bakar tubuh oleh otot yang aktif, juga terjadi reaksi tubuh yang kompleks meliputi fungsi sirkulasi metabolisme, pelepasan dan pengaturan hormonal dan susunan saraf otonom. Pada keadaan istirahat, metabolisme otot hanya sedikit sekali memakai glukosa sebagai sumber bahan bakar, sedangkan saat berolahraga, glukosa dan lemak akan dijadikan sebagai bahan bakar utama. Diharapkan dengan dijadikannya glukosa sebagai bahan bakar utama, kadar glukosa darah akan menurun (Azitha et al., 2018).

Berdasarkan hasil survey awal yang dilakukan pada 14 orang pasien DM, didapatkan bahwa 11 orang pasien telah melakukan aktifitas fisik, tetapi aktifitas fisik dilakukan seperti kondisi biasa saat sebelum terjadi pandemi COVID-19 yaitu jalan kaki diluar rumah dan bertani. Hasil survey awal juga menunjukkan 11 orang pasien memiliki kadar gula darah yang tinggi berdasarkan hasil kadar gula darah yang diperiksa pasien saat berkunjung ke pelayanan kesehatan. 14 orang pasien yang dilakukan survey awal tersebut juga belum pernah mendapatkan edukasi tentang senam kaki pada penderita DM saat pandemi COVID-19.

Upaya pemberdayaan pasien DM dan keluarga dalam melakukan aktifitas fisik perlu dilakukan untuk mengontrol kadar gula darah pasien dan secara khusus juga untuk meningkatkan imunitas pasien di saat pandemi COVID-19 ini. Berdasarkan uraian di atas, salah satu upaya yang dapat dilakukan perawat adalah dengan memberikan edukasi dan latihan senam kaki pada pasien DM di masa pandemi COVID-19. Tujuan 


\section{Jurnal ABDI MERCUSUAR}

Vol. 01, No. 01, Mei, 2021, pp. 017 - 025

dari kegiatan ini yaitu untuk memberikan dukungan kesehatan untuk mencegah amputasi pada penderita diabetes melitus di klinik MERCUBAKTIJAYA Padang sehingga dapat mengurangi resiko terjadinya masalah kesehatan penyakit diabetes melitus.

\section{Metode Pelaksanaan}

Pelaksanaan pengabdian masyarakat dilakukan di klinik MERCUBAKTIJAYA Padang. Metode yang akan dilakukan pada kegiatan pengabdian adalah 1) Strategi Pelaksanaan supaya dapat mencapai target luaran yang telah ditetapkan, maka tim pengabdi merencanakan rancangan pelaksanaan kegiatan ini dilakukan dengan melakukan pendekatan partisipatif dan kelompok, agar pihak klinik MERCUBAKTIJAYA Padang berpartispasi aktif terhadap kegiatan ini dari awal hingga akhir. Selain itu, kegiatan ini mengacu ke langkah-langkah action research. Kegiatannya sebagai berikut a) Perencanaan terdiri dari (1) Melakukan survey awal terkait permasalah yang terjadi pada pasien diabetes melitus akibat dari pandemi COVID-19, (2) Koordinasi dengan penanggung jawab klinik MERCUBAKTIJAYA Padang, (3) Mempersiapkan fasilitas dan saran untuk kelengkapan pengabdian masyarakat. b) Tindakan terdapat dari 4 tahapan yaitu (1) Skrining pada masyarakat dengan masalah kesehatan diabetes melitus dan pemeriksaan Ankle Brachii Index (ABI) sederhana, (2) Memberikan edukasi pada masyarakat tentang penatalaksanaan diabetes melitus. (3) Pembentukan kelompok prolanis DM dan pelatihan senam kaki diabetes pada masyarakat, (4) Monitoring dan evaluasi secara berkala dan berkelanjutan dengan melibatkan klinik. Pemberian materi adalah narasumber dari Tim pengabdi sendiri, dalam hal ini melibatkan mahasiswa sebagai fasilitator yang akan membantu melancarkan kegiatan ini.

Metode Pelaksanaan terdiri dari a) Identifikasi Masalah yaitu sebelum menyusun program ini, Tim pengabdi melakukan identifikasi masalah yang ada di lokasi kegiatan. Masalah-masalah tersebut diketahui dengan cara berdiskusi langsung dengan Pimpinan klinik, penanggung jawab kesehatan yang ada di klinik MERCUBAKTIJAYA Padang. Semua masalah yang ditemui dicatat untuk didiskusikan lebih lanjut dalam tim. Berdasarkan wawancara dengan Pimpinan klinik menyatakan bahwa Masyarakat wilayah Nanggalo Padang merupakan kelompok masyarakat yang menjadi sasaran dari pengabdian masyarakat yang akan dilakukan. b) Analisis Kebutuhan, berdasarkan informasi yang diperoleh dari berbagai pihak dan data-data sekunder, maka tim pengabdi menganalisis kebutuhan khusus tentang penyakit diabetes melitus dan informasi tentang penatalaksanaan diabetes melitus di masa pandemi covid-19 ini pada masyarakat. Dari hasil analisis akan ditemukan masalah yang akan dicarikan solusi dengan cara penyusunan program berdasarkan skala prioritas dan disesuaikan dengan keahlian yang dimiliki. Tahap ini tim pengabdi sudah mengidentifikasi jumlah pasien diabetes melitus yang di butuhkan. c) Penyusunan Program, program disusun berdasarkan skala prioritas dan benar-benar menjadi masalah utama yang ditemukan dilokasi kegiatan. Programnya berupa pemeriksaan ABI sederhana, pemberian edukasi, pembentukan kelompok khusus prolanis DM, monitoring dan evaluasi. Pada tahap ini 


\section{Jurnal ABDI MERCUSUAR}

sudah terbentuknya kelompok prolanis DM. d) Pelaksanaan Program, Setelah program di susun secara detail dan rencana kerja sudah di buat, maka dilaksanakan program tersebut sesuai dengan rencana kerja yang telah ditetapkan. Pelaksanaannya berupa pemeriksaan ABI, pemberian edukasi, pembentukan kelompok prolanis DM, monitoring dan evaluasi, e) Monitoring Evaluasi, selain dilakukan oleh tim pemberi dana juga dilakukan oleh tim internal dari kampus. Tim monitoring melakukan monitoring atas kegiatan yang dilakukan pengabdi apakah kegiatan tersebut sesuai dengan rencana kerja yang sudah ditetapkan seperti proses pelaksanaanya.

\section{Hasil}

Tahap persiapan pada pengabdian masyarakat ini adalah mempersiapkan instrumen pengabdian masyarakat yang akan dilakukan seperti alat-alat yang diperlukan saat pelaksanaan pengabdian serta melakukan koordinasi dengan klinik MERCUBAKTIJAYA Padang. Rangkaian pelaksanaan pengabdian masyarakat yang dilakukan yaitu pemeriksaan ABI sederhana, pemberian edukasi, pembentukan kelompok khusus prolanis DM, monitoring dan evaluasi.

Pelaksanaan pengabdian masyarakat diawali dengan melakukan pemeriksaan nilai ABI pada pasien terdapat dalam tabel berikut.

\section{Tabel 1. Distribusi Frekuensi Nilai ABI Peserta PKM Cegah Amputasi dengan Penatalaksanaan DM di Masa Pandemi Covid-19}

\begin{tabular}{rlcc}
\hline & Nilai ABI & F & \% \\
\hline 1 & Menurun & 0 & 0 \\
\hline 2 & Normal & 10 & 100 \\
\hline 3 & Kekakuan Arteri & 0 & 0 \\
\hline & Total & $\mathbf{1 0}$ & $\mathbf{1 0 0}$
\end{tabular}

Berdasarkan tabel 1 diatas diketahui bahwa nilai pemeriksaan ABI pada Peserta PKM Cegah Amputasi dengan Penatalaksanaan DM di Masa Pandemi Covid-19, didapatkan hasil ABI peserta semuanya dalam rentang normal. Setelah dilakukan pemeriksaan $\mathrm{ABI}$, peserta dilakukan pemberian edukasi. Pemberian edukasi dilaksanakan pada tanggal 15 Desember 2020. Pemberian materi pertama berlangsung selama 60 menit dan materi kedua selama 60 menit dan di lanjutkan dengan 15 menit tanya jawab. Peserta tampak antusias dalam kegiatan, saat evaluasi $90 \%$ peserta mampu menyebutkan kembali tentang materi yang disampaikan.

Pelaksanaan pemberian edukasi kegiatan sesuai dengan rencana, dimulai pukul 10.00 - 12.15 WIB. Jumlah peserta yang hadir saat kegiatan pengabdian masyarakat adalah 10 orang. Setting media dan alat-alat yang digunakan sesuai dengan direncanakan yaitu dengan menggunakan media LCD, video dan wireless. 


\section{Jurnal ABDI MERCUSUAR}

Vol. 01, No. 01, Mei, 2021, pp. 017 - 025

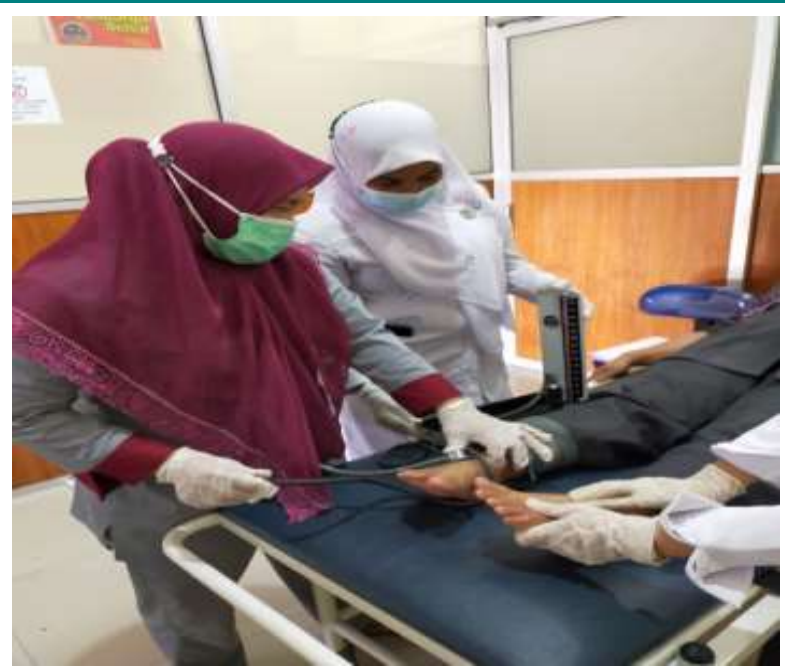

Gambar 1. Pemeriksaan ABI Sederhana PKM Cegah Amputasi dengan Penatalaksanaan DM di Masa Pandemi Covid-19

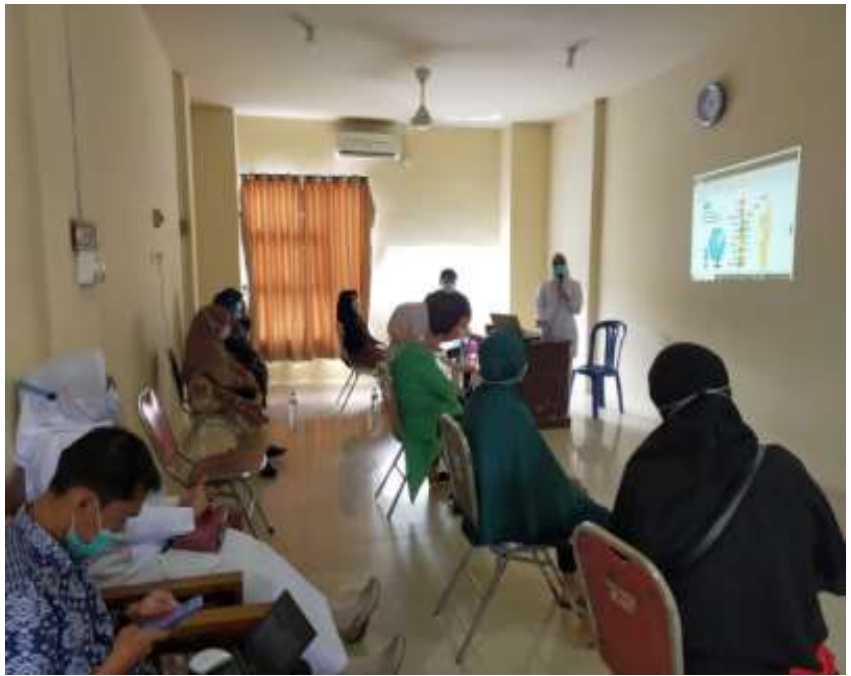

Gambar 2. Penyampaian Materi tentang PKM Cegah Amputasi dengan Penatalaksanaan DM di Masa Pandemi Covid-19

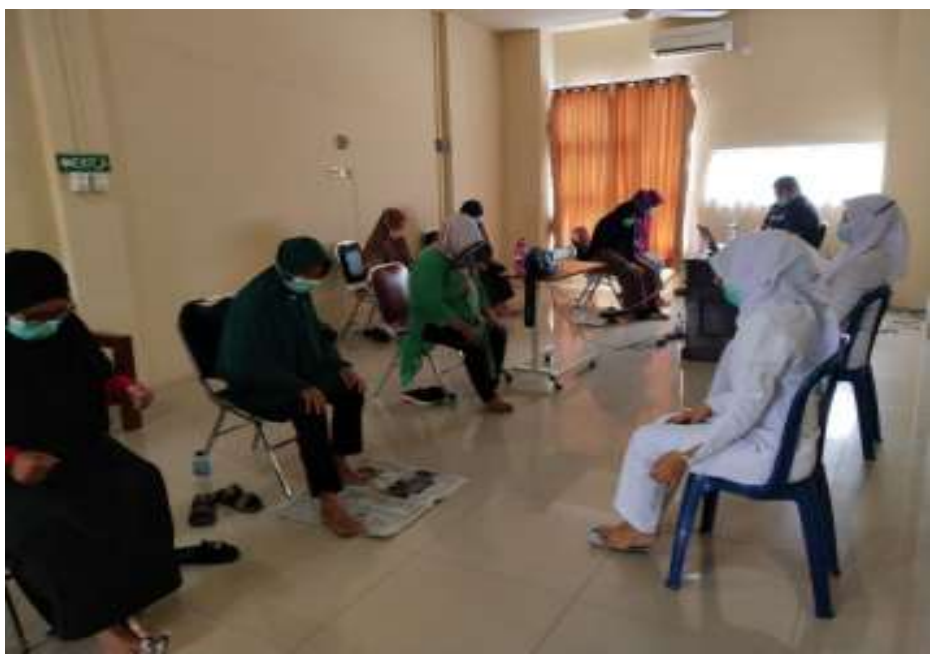

Gambar 3. Pelaksanaan Senam Kaki Diabetik PKM Cegah Amputasi dengan Penatalaksanaan DM di Masa Pandemi Covid-19 


\section{Diskusi}

Nilai pemeriksaan ABI pada Peserta PKM Cegah Amputasi dengan Penatalaksanaan DM di Masa Pandemi Covid-19, didapatkan hasil ABI peserta semuanya dalam rentang normal. Setelah dilakukan pemeriksaan ABI, peserta dilakukan pemberian edukasi. Pemberian edukasi ini membahas tentang penyakit diabetes mellitus dan penatalaksanaan diabetes mellitus dengan senam kaki diabetes pada masa pandemi covid-19. Selanjutnya dengan pemberian edukasi ini hendaknya penderita DM bisa tetap melaksanakan aktifitas fisik ringan dengan kegiatan senam kaki diabetik ini walaupun hanya didalam rumah untuk bisa mencegah dampak buruk yang biasa terjadi pada penderita DM. Senam kaki direkomendasikan dilakukan dengan intensitas moderat (60-70\% maksimum heart rate), durasi 30-60 menit, dengan frekuensi 3-5 kali per minggu dan tidak lebih dari 2 hari berturut-turut tidak melakukan senam (Nurlinawati et al., 2018). Senam kaki diabetik juga dapat meningkatkan kekuatan otot betis dan otot paha dan juga dapat mempertahankan pergerakan sendi secara normal. Otot-otot bergerak aktif akan berpengaruh terhadap perubahan kadar gula darah yaitu pada otot-otot yang bergerak aktif dapat meningkatkan kontraksi sehingga permeabilitas membran sel terhadap pemecahan glukosa (Widiawati et al., 2020).

Pelaksanaan senam kaki ini sejalan dengan penelitian yang dilakukan oleh (Nurlinawati et al., 2018) dimana setelah dilakukan senam kaki diketahui bahwa sebanyak 11 (100\%) responden pada kelompok intervensi mengalami penurunan kadar gula darah. Kondisi penderita DM yang mengalami kelelahan, tidak banyak aktivitas membuat sirkulasi darah tidak lancar dan dapat diatasi dengan latihan fisik yaitu senam kaki diabetes. Langkah-langkah senam kaki diabetes ini merupakan langkah yang tidak sulit dilakukan oleh penderita DM yang memberi dampak positif terhadap sirkulasi darah klien kebagian kaki dengan hasil mengurangi edema dan tanda-tanda luka atau ulkus tidak ditemui. Waktu yang digunakan oleh klien untuk latihan senam kaki diabetes ini cukup 30 menit dengan delapan langkah kegiatan senam kaki diabetes dapat menurunkan Gula Darah penderita diabetes mellitus (Widiawati et al., 2020).

\section{Kesimpulan dan Saran}

Masalah penyakit Diabetes Melitus (DM) merupakan gangguan metabolisme kronis yang ditandai dengan tingginya kadar gula darah sebagai akibat insufisiensi fungsi insulin yang disebabkan oleh gangguan produk insulin oleh sel beta langerhans atau kurang responsifnya sel tubuh terhadap insulin. Covid-19 menyerang hampir seluruh kalangan usia terutama orang yang mempunyai riwayat penyakit kronis (komorbid) memiliki risiko untuk terkena lebih sering dan dengan komplikasi yang lebih buruk dari penyakit ini. Riwayat penyakit kronis salah satunya adalah DM. Latihan fisik atau aktifitas fisik (senam kaki Diabetik) merupakan salah satu pilar dalam pengelolaan DM yang berfungsi untuk memperbaiki sensitivitas insulin dan juga untuk menjaga kebugaran tubuh di masa Pandemi COVID-19. Banyak dampak yang akan timbul jika 


\section{Jurnal ABDI MERCUSUAR}

Vol. 01, No. 01, Mei, 2021, pp. 017 - 025

tidak diatasi dengan segera misalnya terjadinya amputasi. Pemberian edukasi dan Pembentukan kelompok prolanis DM diharapkan dapat menjadikan tempat untuk bertambahnya wawasan pengetahuan dan cara pencegahan dini penatalaksanaan pada penderita DM agar tidak terjadinya amputasi pada pasien DM dimasa pandemi covid 19 ini khususnya pada masyarakat di wilayah nanggalo Padang.

\section{Pengakuan/Acknowledgements}

Pelaksanaan kegiatan ini tidak lepas dari bantuan dan dukungan dari berbagai pihak. Pada kesempatan ini kami mengucapkan terima kasih kepada Yayasan dan STIKes MERCUBAKTIJAYA Padang, LPPM STIKes MERCUBAKTIJAYA Padang serta Pimpinan Klinik MERCUBAKTIJAYA Padang yang telah membantu dan memfasilitasi kegiatan pengabdian masyarakat ini.

\section{Daftar Referensi}

Azitha, M., Aprilia, D., \& Ilhami, Y. R. (2018). Hubungan Aktivitas Fisik dengan Kadar Glukosa Darah Puasa pada Pasien Diabetes Melitus yang Datang ke Poli Klinik Penyakit Dalam Rumah Sakit M. Djamil Padang. Jurnal Kesehatan Andalas, 7(3), 400. https://doi.org/10.25077/jka.v7i3.893

Hasil-riskesdas-2018_1274. (n.d.).

Masriadi. (2016). Epidemiologi Penyakit Tidak Menular. TIM.

Nurlinawati, Kamariyah, Y, D., \& Uliana. (2018). Pengaruh Senam Kaki Diabetes Terhadap Perubahan Kadar Gula Darah Pada Penderita Diabetes Me Litus Di Wilayah Kerja Puskesmas Simpang Sungai Duren Kabupaten Muaro Jam. Jurnal Ilmiah Ilmu Terapan Universitas Jambi, 1(Dm), 1-26.

Onder, G., Rezza, G., \& Brusaferro, S. (2020). Case-Fatality Rate and Characteristics of Patients Dying in Relation to COVID-19 in Italy. JAMA - Journal of the American Medical Association, 323(18), 1775-1776. https://doi.org/10.1001/jama.2020.4683

PERKENI. (2020). Pernyataan Resmi dan Rekomendasi Penanganan Diabetes Mellitus di era Pandemi COVID-19. The Indonesian Society of Endocrinology, 1-5.

Tandra, H. (2017). SEGALA SESUATU YANG HARUS ANDA KETAHUI TENTANG DIABETES. Widiawati, S., Maulani, M., \& Kalpataria, W. (2020). Implementasi Senam Kaki Diabetes Pada Penderita Diabetes Melitus di RSUD Raden Mattaher Jambi. Jurnal Pengabdian Harapan Ibu (JPHI), 2(1), 6. https://doi.org/10.30644/jphi.v2i1.199

$\mathrm{Wu}, \mathrm{Z}$., \& McGoogan, J. M. (2020). Characteristics of and Important Lessons from the Coronavirus Disease 2019 (COVID-19) Outbreak in China: Summary of a Report of 72314 Cases from the Chinese Center for Disease Control and Prevention. JAMA Journal of the American Medical Association, 323(13), 1239-1242. https://doi.org/10.1001/jama.2020.2648

Yang, J., Zheng, Y., Gou, X., Pu, K., Chen, Z., Guo, Q., Ji, R., Wang, H., Wang, Y., \& Zhou, Y. (2020). Prevalence of comorbidities and its effects in coronavirus disease 2019 


\section{Jurnal ABDI MERCUSUAR}

Vol. 01, No. 01, Mei, 2021, pp. 017 - 025

patients: A systematic review and meta-analysis. International Journal of Infectious Diseases, 94, 91-95. https://doi.org/10.1016/j.ijid.2020.03.017

Yuen, L., Saeedi, P., Riaz, M., Karuranga, S., Divakar, H., Levitt, N., Yang, X., \& Simmons, D. (2019). IDF Diabetes Atlas: Projections of the prevalence of hyperglycaemia in pregnancy in 2019 and beyond: Results from the International Diabetes Federation Diabetes Atlas, 9th edition. Diabetes Research and Clinical Practice, 157, 107841. https://doi.org/10.1016/j.diabres.2019.107841 